\title{
Evaluation of biofilm formation activity of standard microorganism strains
}

\section{Standart mikroorganizma suşlarının biyofilm formasyon aktivitelerinin değerlendirilmesi}

\author{
Uğur Tutar ${ }^{1}$, Cem Çelik², Mehmet Ataş3 ${ }^{3}$ Tutku Tunç3, Mustafa Gökhan Gözel ${ }^{4}$
}

\begin{abstract}
Objective: Biofilm is a structure formed by a group of microorganisms. Bacteria in the biofilm lead to much more serious problems in medical and industrial terms when compared to their planktonic forms. In this sense, it is important to know about the biofilm activities of the microorganisms. The ability of certain microorganism strains to form biofilms was shown, and the importance of this subject was tried to be emphasized in this study.

Methods: Fifteen bacteria and two yeast standard strains were used in the study. Microtiter plate method was used in order to determine the biofilm production capacities of standard strains. Biofilm formations were assessed as "nonadherent $=0$, weakly adherent $=I$, moderately adherent = II and strongly adherent =III."
\end{abstract}

Results: Biofilm formation was observed in all of the 17 standard strains following the study carried out. Among standard microorganisms, Pseudomonas aeruginosa, Staphylococcus aureus, Corynebacterium pseudotuberculosis and Neisseria sicca created a strong biofilm.

Conclusion: It is known that biofilms formed by microorganisms lead to negative consequences in human health. Therefore it's important to study on understanding biofilm formations. We believe that the biofilm formation data of the standard microorganisms we provide in our study will contribute to the researchers to conduct researches on this subject and the literature related to the subject. J Clin Exp Invest 2015; 6 (2): 135-139

Key words: Biofilm, microtiter plate method, antimicrobial resistance, standard strain

\section{INTRODUCTION}

Biofilm is the structure formed by the microorganisms by sticking to each other in the extracellular

\section{ÖZET}

Amaç: Biyofilm mikroorganizmaların meydana getirdikleri bir yapıdır. Biyofilm içerisindeki bakteriler, planktonik formları ile kıyaslandığında tıbbi ve endüstriyel açıdan çok daha önemli sorunlara neden olmaktadır. Bu bakımdan mikroorganizmaların biyofilm aktivitelerinin bilinmesi önemlidir. Bu çalışmada bazı mikroorganizma suşlarının biyofilm oluşturabilme yetenekleri gösterilerek bu konunun önemi vurgulanmaya çalışılmıştır.

Yöntemler: Çalışmada 15 adet bakteri ve iki adet maya standart suşu kullanılmıştır. Standart suşların biyofilm üretim kapasitelerinin belirlenmesi amacıyla mikrotitre plak yöntemi kullanılmıştır. Biyofilm formasyonları negatif kontrol değeri baz alınarak 'biyofilm oluşturmayan $=0$, zayıf biyofilm = I, orta dereceli biyofilm = II ve güçlü biyofilm =III olarak değerlendirilmiştir.

Bulgular: Yapılan çalışma sonrasında 17 adet standart suşun tamamında biyofilm oluşumu gözlenmiştir. Standart mikroorganizmalardan Pseudomonas aeruginosa, Staphylococcus aureus, Corynebacterium pseudotuberculosis ve Neisseria sicca güçlü biyofilm oluşturmuşlardır.

Sonuç: Mikroorganizmaların oluşturdukları biyofilmlerin insan sağlığı açısından olumsuz sonuçlara yol açtığı bilinmektedir. Bu bakımdan biyofilm formasyonlarının anlaşılması ile ilgili yapılacak çalışmalar önemlidir. Çalışmamızda sunduğumuz standart mikroorganizmalara ait biyofilm formasyon verilerinin bu konuda çalışma yapacak araştırıcılara ve konuyla ilgili literatüre katkı sağlayacağını düşünmekteyiz.

Anahtar kelimeler: Biyofilm, mikrotitre plak yöntemi, antimikrobiyal direnç, standart suş

matrix, also called the "glycocalyx", formed after their adhesion to biotic or abiotic surfaces in order to percept the environment by means of various signal molecules with a mechanism named as quorum

\footnotetext{
${ }^{1}$ Department of Nutrition and Dietetics, Cumhuriyet University Faculty of Health Sciences, Sivas, Turkey

${ }^{2}$ Department of Medical Microbiology, Cumhuriyet University Faculty of Medicine, Sivas, Turkey

${ }^{3}$ Department of Pharmaceutical Microbiology, Cumhuriyet University Faculty of Pharmacy, Sivas, Turkey

${ }^{4}$ Department of Infectious Diseases and Clinical Microbiology, Cumhuriyet University Faculty of Medicine, Sivas, Turkey
}

Correspondence: Uğur Tutar,

Cumhuriyet University Faculty of Health Sciences, Dept. Nutrition and Dietetics, Sivas, Turkey Email: ututar5@gmail.com

Received: 05.04.2015, Accepted: 25.04.2015

Copyright @ JCEI / Journal of Clinical and Experimental Investigations 2015, All rights reserved 
sensing and ensure the communication between cells. This structure may exhibit different phenotype characteristics by the growth speed and gene transcriptions of the microorganisms [1-3].

By forming a biofilm, microorganisms protect themselves against physical and chemical stresses, as well as phagocytosis. Furthermore, it is seen that bacteria forming biofilm are much more resistant against antibiotics than planktonic cells [4-5]. The most important factor creating this resistance is that the biofilm decreases the effectiveness of antibacterial agents by preventing their penetration by forming a barrier [6].

The biofilm layer can be encountered in all surfaces coming in contact with water, such as industrial and domestic water systems. It is also seen that it can develop on many different surfaces such as medical implants; and lead to infections [7-9].

Certain studies carried out put forth that biofilms formed by microorganisms are responsible for approximately $65 \%$ of nosocomial infections, and this increases the costs of treatment significantly [10].

National Institutes of Health (NIH) emphasizes that $70 \%$ of world microbial infections are related to biofilm. In this sense, important studies have been carried out recently on biofilm formations and antibiofilm agents [7].

As we believe the studies to be carried out with the aim of understanding the biofilm formation mechanisms of microorganisms well and preventing their formation would be important, we wanted to show the biofilm formation data of standard strains of the microorganisms threatening the environment and human health in our study altogether. Thus, we hope our study will contribute to the researches to be carried out on this subject and the literature.

\section{METHODS}

The microtiter plate method was used in order to determine the biofilm production capacities of standard strains. 15 bacteria and two yeast standard strains were used in the study (Table 2). The standard bacteria strains were incubated for 24 hours at $37^{\circ} \mathrm{C}$ by means of passaging to the blood agar plate, and yeast strains were incubated for 48 hours at $37^{\circ} \mathrm{C}$ by means of passaging to the Sabouraud Dextrose Agar (SDA) plates. Strains to be used in the study were suspended in tryptic soy broth (TSB) which was added $0.25 \%$ glucose, and incubated for one night. The suspensions were prepared in accordance with 0.5 Mcfarland sliding scale, and it was ensured that each of them is $10^{8} \mathrm{CFU} / \mathrm{ml}$. 200 $\mu \mathrm{l}$ was taken from the suspensions and transferred to the microtiter plate with 96 wells. TSB without the addition of $200 \mu$ bacteria suspension was used as a negative control. The wells were slowly emptied in order to eliminate planktonic cells in the wells following the one-night incubation at $37^{\circ} \mathrm{C}$, and washed with phosphate- buffer saline (PBS) twice. The biofilms formed were dyed by adding $200 \mu \mathrm{l}$ crystal violet of $0.1 \%$ to the wells dried at room temperature. After waiting for 30 minutes, the wells were emptied by washing twice with PBS once again. The absorbance values at $550 \mathrm{~nm}$ were read in Triturus microelisa (Norcross, GA, USA) device by adding ethanol of $95 \%$ to the wells dried at room temperature. Biofilm formations were evaluated in accordance with the scale reported by Csuhri et al. based on the negative control absorbance value [11] (Table 1).

Table 1. Assessment scale for the biofilm formation of microorganisms

\begin{tabular}{lll}
\hline OD cont $>$ OD MB & Nonadherent & 0 \\
OD cont < OD MB < 2 OD cont & Weakly adherent & । \\
2 OD cont < OD MB < 4 OD cont Moderately adherent & II \\
4 OD cont < OD MB & Strongly adherent & III \\
\hline
\end{tabular}

OD: Optical Density, OD MB: Optical Density of microorganisms biofilm, Adherent: Create a level of biofilm,

The study was performed in three repetitions. Biofilm formation activities of each microorganism were graded by the above mentioned scale by calculating the arithmetic mean and standard deviation of the values obtained. Our research was carried out with the suitability decision of Cumhuriyet University, Faculty of Medicine, Head of the Ethics Committee.

\section{RESULTS}

As a result of the study carried out, biofilm formations of 17 standard strains were graded by their absorbance values (Table 2). While five of these strains created weak and eight created medium, Pseudomonas aeruginosa, Staphylococcus aureus, Corynebacterium pseudotuberculosis and Neisseria sicca created a strong biofilm. 
Table 2. Biofilm formation activities of standard microorganism strains

\begin{tabular}{|c|c|c|c|c|c|c|}
\hline \multirow{2}{*}{ Microorganisms } & \multirow{2}{*}{ OD Control } & \multicolumn{3}{|c|}{ OD MB } & \multirow{2}{*}{ Mean OD \pm SD } & \multirow{2}{*}{ Adherent } \\
\hline & & I & II & III & & \\
\hline Proteus vulgaris (ATCC 7829) & 0,289 & 0,682 & 0,702 & 0,752 & $0,712 \pm 0,036$ & II \\
\hline Salmonella typhi (ATCC 14028) & 0,289 & 0,436 & 0,424 & 0,461 & $0,440 \pm 0,018$ & I \\
\hline Shigella dysenteriae (ATCC 11835) & 0,289 & 0,651 & 0,802 & 0,681 & $0,711 \pm 0,079$ & II \\
\hline Shigella boydii (ATCC 9905) & 0,289 & 0,690 & 0,560 & 0,596 & $0,615 \pm 0,067$ & II \\
\hline Bacillus cereus (ATCC 10987) & 0,289 & 0,491 & 0,431 & 0,616 & $0,512 \pm 0,094$ & I \\
\hline Neisseria sicca (ATCC 9913) & 0,289 & 1,639 & 1,202 & 1,828 & $1,556 \pm 0,321$ & III \\
\hline Bacillus subtilis (ATCC 6633) & 0,289 & 0,523 & 0,499 & 0,561 & $0,527 \pm 0,031$ & I \\
\hline $\begin{array}{l}\text { Corynebacterium pseudotuberculosis } \\
\text { (ATCC 19410) }\end{array}$ & 0,289 & 1,583 & 1,920 & 1,428 & $1,643 \pm 0,251$ & III \\
\hline Streptococcus pyogenes (ATCC 19615) & 0,289 & 0,561 & 0,610 & 0,575 & $0,582 \pm 0,025$ & II \\
\hline Streptococcus mutans (ATCC 21752) & 0,289 & 1,072 & 0,998 & 0,885 & $0,985 \pm 0,094$ & II \\
\hline Streptococcus sanguinis (ATCC 10557) & 0,289 & 0,905 & 0,927 & 0,943 & $0,925 \pm 0,019$ & II \\
\hline Klebsiella pneumoniae (ATCC 10031) & 0,289 & 0,419 & 0,434 & 0,669 & $0,507 \pm 0,140$ & I \\
\hline Escherichia coli (ATCC 11229) & 0,289 & 0,851 & 1,005 & 1,112 & $0,989 \pm 0,131$ & II \\
\hline Pseudomonas aeruginosa (ATCC 27853) & 0,289 & 2,268 & 2,264 & 2,331 & $2,287 \pm 0,037$ & III \\
\hline Staphylococcus aureus (ATCC 25923) & 0,289 & 1,639 & 1,402 & 1,327 & $1,456 \pm 0,162$ & III \\
\hline Candida albicans (ATCC 10231) & 0,289 & 0,499 & 0,427 & 0,501 & $0,475 \pm 0,042$ & I \\
\hline Candida tropicalis (ATCC 750) & 0,289 & 0,822 & 0,915 & 1,087 & $0,941 \pm 0,134$ & II \\
\hline
\end{tabular}

OD: Optical Density, OD MB: Optical Density of microorganisms biofilm, Adherent: Create a level of biofilm, SD: Standard deviation

\section{DISCUSSION}

At the present time, it is known that the biofilms can be formed in many natural ecosystems [12]. While people used to think that biofilms only lead to industrial problems, it is now known that they lead to significant problems affecting the environment and public health and play a part in many chronic infections [13]. The communication system from cell to cell named as quorum sensing is held responsible for the formation of biofilm [14].

In the study we carried out, it was detected that standard microorganisms create biofilms at different levels (Table 2). We saw that the Pseudomonas aeruginosa ATCC 27853 strain created a strong biofilm. P.aeruginosa is an opportunist pathogen that is frequently isolated from serious infections. In a study carried out, it was expressed that these bacteria form biofilms in water treatment facility units, and pose a significant threat in terms of the environment and human health in this sense [15]. P.aeruginosa may show a "suitable" pathology for the microenvironmental conditions, and is one of the most significant pathogenity criteria in order for the biofilm to form [16]. This bacteria lead to the contamination of the medical tools-equipment in the hospitals and the formation of hospital infections with its ability to easily proliferate in aqueous environments. Furthermore, it was also stated that it can lead to infections related to the use of swimming pool, jacuzzi and contact lenses in healthy people outside the hospital [17]. As we detected in our study, the standard strain of P.aeruginosa can form a strong biofilm. In this sense, we believe the necessary precautions should be sensitively taken in consideration of the biofilm formation ability in the environments.

Pathogenic Staphylococcus species which are significantly threaten human health. S.aureus and Staphylococcus epidermidis is a factor in the formation of many infections in human such as respiratory tract infections, catheter infections, meningitis, septicemia, arthritis, dermatitis, endocarditis, thrombophlebitis $[18,19]$. Furthermore, these bacteria can also form a biofilm by sticking to the surfaces where food is produced, and thus cause the continuity of the contamination in the production line. In different studies carried out, it was stated that the biofilm formation rates of $S$. aureus isolates are between $50 \%$ and $68.6 \%$ [20-22]. It was reported that the biofilm created by $S$. aureus may pose a risk for public 
health by generating resistance against antibiotics, disinfectants and immune-defense elements, and may also lead to economic losses by causing deterioration in food $[23,24]$. According to the result of our study, it is seen that the S.aureus ATCC 25923 strain may create a strong biofilm. It is especially important for the existence of this bacterium to be detected in hospital and food production areas, and foresee the negative consequences it may lead to with the effect of the biofilm it forms.

It is seen that Candida albicans ATCC 10231 and Candida tropicalis ATCC 750 strains we included in our study form weak and medium level biofilms, respectively. In the studies carried out, it was reported that the biofilm rates detected in Candida species vary between $8-85 \%[25,26]$. It was stated that the Candida isolates that can form biofilms have a high amphotericin B MIC level; and that this medicine shows 100 times less effectiveness against the cells in the biofilm when compared to planktonic cells. It was expressed that this constitutes a significant problem in the treatment, and may lead to an increase in Candida infections related to catheter [27].

It is known that many microorganisms become more effective by creating biofilms [12]. For example, it is expressed that Streptococcus mutans increases its virulence by creating a biofilm in its external surfaces [28], and N. sicca can develop pathologies such as metaplasia, abscess and endometritis in human and animals [29]. It was emphasized that Proteus vulgaris can form biofilms by clinging even on steel surfaces, whereby both threatening the hospital hygiene in the field of health and also leading to the contamination of the food substances produced in the food industry $[30,31]$. In the studies carried out, it was reported that bacteria such as Klebsiella pneumoniae, Escherichia coli can create resistant strains in hospitals as a result of their ability to generate biofilms [32,33], Salmonella lead to new contaminations by means of the biofilms they form by clinging to various surfaces [34], and Bacillus species lead to significant economic losses in food industry as a result of the biofilms they create [35].

Considering the structures, effects and consequences of the biofilms, we believe the studies to be carried out on the detection of biofilm formations of the microorganisms, the determination of how and under what conditions the biofilms form, their general structure, and biofilm formation will be very significant.
We believe the biofilm formation activities we determined at different levels in 17 standard microorganism strains we provided in our study will contribute to the researchers who will carry out studies on this subject and the relevant literature.

\section{REFERENCES}

1. Abdi-Ali A, Hendiani S, Mohammadi P, Gharavi S. Assessment of biofilm formation and resistance to imipenem and ciprofloxacin among clinical isolates of Acinetobacter baumannii in Tehran. Jundishapur $\mathrm{J}$ Microbiol 2014;7:e8606.

2. Boşgelmez-Tınaz G. Quorum sensing in gram-negative bacteria. Turk J Biol 2003;27:85-93.

3. Rao RS, Karthika RU, Singh SP, et al. Correlation between biofilm production and multiple drug resistance in imipenem resistant clinical isolates of Acinetobacter baumannii. Indian J Med Microbiol 2008;26:333-337.

4. Costerton Cucarella C, Tormo MA, Ubeda C, et al. Role of biofilm associated protein Bap in the pathogenesis of bovine Staphylococcus aureus. Infect Immun 2004;72:2177-2178.

5. Christensen GD, Simpson WA, Younger JJ, et al. Adherence of coagulase-negative staphylococci to plastic tissue culture plates: A quantitative model for the adherence of staphylococci to medical devices. J Clin Microbiol 1985;22:996-1006.

6. Suci PA, Mittelman MW, Yu FP, Geesey GG. Investigation of ciprofloxacin penetration into Pseudomonas aeruginosa biofilms. Antimicrob Agents Chemother 1994;38:2125-2133.

7. Costerton JW, Stewart PS, Greenberg EP. Bacterial biofilms: a common cause of persistent infections. Science 1999;284:1318-1322.

8. Donlan RM, Costerton JW. Biofilms: survival mechanisms of clinically relevant microorganisms. Clin Microbiol Rev 2002;15:167-193.

9. Altun HU, Şener B. Biofilm infections and antimicrobial resistance Hacettepe Medical Journal 2008;39:82-88.

10. Öztürk ŞB, Sakarya S, Öncü S, Ertuğrul MB. Biofilm and device-associated infections. Klimik Dergisi 2008;21:79-86.

11. Chusri S, Phatthalung PN, Voravuthikunchai SP. Antibiofilm activity of Quercus infectoria G. Olivier against methicillin-resistant Staphylococcus aureus Lett Appl Microbiol 2012;54:511-517.

12. Costerton JW, Lewandowski Z, Caldwell DE, et al. Microbial biofilms. Annu Rev Microbiol 1995;49:711-745.

13. Akbaş E. Basic principles in investigation of Legionella in hospital water systems. Türk Mikrobiyoloji Cemiyeti Dergisi 2013;43:1-11.

14. Karaman M, Yılmaz O, Bayrakal V, Bahar İH. Pseudomonas aeruginosa quorum sensing responses and biofilm production under the influence of gentamicin 
and imipenem: In vivo modelling ANKEM Dergisi 2010;24:76-81.

15. Naz I, Batool SA, Ali N, et al. Monitoring of growth and physiological activities of biofilm during succession on polystyrene from activated sludge under aerobic and anaerobic conditions. Environ Monit Assess 2013;185:6881-6892.

16. Bayrakal V, Baskın H, Bahar İH. Experimental microenvironment modeling study: quorum sensing and biofilm responses of Pseudomonas aeruginosa in different cell lines Türkiye Klinikleri J Med Sci 2009;29:637-642.

17. Mataracı A, Gerçeker AA. Evaluation of the minimum bactericidal concentrations of various disinfectants against Pseudomonas aeruginosa in biofilm cultures. ANKEM Dergisi 2011;25:209-214.

18. Kloos WE, Bannerman TL. Update on clinical significance of coagulase negative Staphylococcus. Clin Microb Rev 2005;7:117-140.

19. Göçmen SJ, Büyükkoçak Ü, Çağlayan O. Effect of parenteral nutrition solutions on biofilm formation of coagulase-negative Staphylococci: An experimental study. J Clin Exp Invest 2012;3:505-509.

20. Gündoğan N, Çıtak S, Turan E. Slime production, DNase activity and antibiotic resistance of Staphylococcus aureus isolated from raw milk, pasteurized milk and ice cream samples. Food Cont 2006;17:389-392.

21. Çıtak S, Varlık O, Gündoğan N. Slime production and DNase activity of staphylococci isolated from raw milk. J Food Safety 2003;23:281-288.

22. Vasudevan P, Nair MKM, Annamali T, Venkitanarayanan KS. Phenotypic and genotypic

characterization of bovine mastitis isolates of Staphylococcus aureus for biofilm formation. Vet Microbiol 2003;92:179-185.

23. Gündoğan N, Ataol Ö. Determination of biofilm production and DNase activity of S. aureus and coagulase negative staphylococci isolated from meat samples Türk Hijyen ve Deneysel Biyoloji Dergisi 2012;69:135-142.

24. Yarwood JM, Bartels DJ, Volper EM, Greenberg EP. Quorum sensing in Staphylococcus aureus biofilms. J Bacteriol 2004; 186:1838-1850.
25. Ramage G, Vandewalle K, Wickes BL, Lopez-Ribot JL. Characteristics of biofilm formation by Candida albicans. Rev Iberoam Micol 2001;18:163-170.

26. Shin JH, Kee SJ, Shin MG, et al. Biofilm production by isolates of Candida species recovered from nonneutropenic patients: comparison of bloodstream isolates with isolates from other sources. J Clin Microbiol 2002;40:1244-1248.

27. Demirbilek M, Timurkaynak F, Can F, et al. Biofilm production and antifungal susceptibility patterns of Candida species isolated from hospitalized patients Mikrobiyol Bült 2007;41:261-269.

28. Yoshida A, Ansai T, Takehara T, Kuramitsu HK. LuxSbased signaling affects Streptococcus mutans biofilm formation. Appl Environ Microbiol 2005;71:2372-2380.

29. Berger SA Gorea A, Peyser MR, Edberg SC. Bartholin's gland abscess caused by Neisseria sicca. J Clin Microbiol 1988;26:1589.

30. Myszka K, Czaczyk K. Effect of starvatıon stress on morphological changes and production of adhesive exopolysaccharide (eps) by Proteus vulgaris Acta Sci Pol Technol Aliment 2011;10:303-312.

31. Shikh-Bardsiri H, Shakibaie MR. Antibiotic resistance pattern among biofilm producing and non producing Proteus strains isolated from hospitalized patients; matter of hospital hygiene and antimicrobial stewardship. Pak J Biol Sci 2013;16:1496-1502.

32. Bandeira M, Carvalho PA, Duarte A, Jordao L. Exploring dangerous connections between Klebsiella pneumoniae biofilms and healthcare-associated infections. Pathogens 2014;19:720-731.

33. Monte J, Abreu AC, Borges A, et al. Antimicrobial activity of selected phytochemicals against Escherichia coli and Staphylococcus aureus and their biofilms. Pathogens 2014;3:473-498.

34. Prodduk V, Annous BA, Liu L, Yam KL. Evaluation of chlorine dioxide gas treatment to inactivate Salmonella enterica on mungbean sprouts. J Food Prot 2014;77:1876-1881.

35. Pasvolsky R, Zakin V, Ostrova I, Shemesh M. Butyric acid released during milk lipolysis triggers biofilm formation of Bacillus species. Int J Food Microbiol 2014;181:19-27. 